TEME, г. XLIV, бр. 1, јануар - март 2020, стр. 1-16

\begin{tabular}{lr}
\hline \hline Оригинални научни рад & https://doi.org/10.22190/TEME191103005D \\
Примљено: 3. 11. 2019. & UDK 336.71(497.11) \\
Ревидирана верзија: 10. 2. 2020. & $338.23: 336.74$ \\
Одобрено за штампу: 20. 2. 2020. &
\end{tabular}

\title{
ABOUT THE LEGAL RESPONSIBILITY OF THE CENTRAL BANK IN MONETARY LAW
}

\author{
Marko Dimitrijević*, Srđan Golubović \\ University of Niš, Faculty of Law, Niš, Serbia \\ *markod1985@prafak.ni.ac.rs
}

\begin{abstract}
The subject of the analysis in this paper is to identify and evaluate the concept of central bank legal responsibility in the contemporary monetary law. In this regard, the research focuses on issues related to the need of clarifying and defining the nature, type and extent of central bank liability and compensation mechanisms for damage that may be caused to third parties in the implementation of the transferred lex monetae in practice. The first part of the paper focuses on the axiological and dogmatic analyses of the legal framework of the central bank, which is governed by the national monetary legislation sui generis, and the interpretation of different legislative solutions in the practice of comparative monetary law in the area of responsibility and legal protection of the central bank. The subject of special interest of the authors is the monetary-legal analysis of the relevant provisions of the Law on the National Bank of Serbia, since in their opinion, a clear determination of the responsibility of the supreme monetary institution is a precondition for its credibility, not only in national but also in the international monetary order, and a conditio sine qua non of creating a reputable and consistent national monetary jurisdiction.
\end{abstract}

Key words: central bank, monetary law, legal liability, lex monetae, monetary legislation, monetary jurisdiction.

\section{О ПРАВНОЈ ОДГОВОРНОСТИ ЦЕНТРАЛНЕ БАНКЕ У МОНЕТАРНОМ ПРАВУ}

\footnotetext{
Апстракт

Предмет анализе у овом раду јесте идентификовање, анализа и оцена концепта правне одговорности централне банке у савременом монетарном праву. У том смислу се у истраживању акценат ставља на питања која се тичу потребе за јасним дефинисањем природе, врсте и степена одговорности централне банке и начина надокнаде евентуалне штете која може бити проузрокована трећим лицима приликом имплементације трансферисаног lex monetae у пракси. У првом делу рада пажња се посвећује аксиолошкој и догматској анализи правног оквира деловања централне банке који се уређује националном монетарном легислативом sui generis и тумачењу различитих законодавних решења у пракси упоредног монетарног права у делу
} 
одговорности и правне заштите централне банке. У даљем тексту, предмет нарочитог интересовања аутора јесте монетарноправна анализа меродавних одредаба Закона о Народној банци Србије, јер је према њиховом мишљењу, јасно одређивање одговорности врховне монетарне институције предуслов њеног кредибилитета, не само у националном, већ и у међународном монетарном поретку, као и conditio sine qua non стварања угледне и конзистентне националне монетарне јурисдикције.

Кључне речи: централна банка, монетарно право, правна одговорност, lex monetae, монетарна легислатива, монетарна јурисдикција.

\section{INTRODUCTION}

Until the late $17^{\text {th }}$ century, the notion of the central bank had an ambiguous meaning, and there was no clear definition about the central bank functions. Central banks, as we perceive them today in monetary law, were constituted and formed during the $19^{\text {th }}$ century. Certain central banks had started their development in the private sector, acting as neutral clearing houses for the already existing commercial banks (Arner, Panton, Lejot, 2010, pp. 2-3). The first central banks did not perform the functions and tasks that are today regarded as their constants in contemporary monetary law, but rather resembled special state bodies, without institutional and any other autonomy (Goodhart, 1991, p. 10). Today's central banks are most often organized as (quasi) government agencies, rarely as privately owned institutions, although combinations of these regimes can be possible in practice. The evolution of central banks, from the emergence of the first central banks (in the UK, France and Sweden), to the establishment of the European Central Bank (ECB) as a complex supranational monetary institution, has taken almost five centuries. In this respect, we can clearly see the development path of central banks law and the development of their microeconomic and macroeconomic functions, which demonstrate the necessity of their existence. It is important to point out that the final status formation of central banks was preceded by the global recognition of the central bank institution as an independent currency guardian, both in academia and among political entities (Smits, 1997, p.153). According to this concept, all issues related to the use of money should be handled by an independent institution, which in its work would be limited only by the concept of democratic legitimacy, the obligation to submit reports, to consult with various political bodies beforehand and to perform public tasks displaced from the sphere of everyday political processes (but normatively very clearly regulated). The positive monetary law, ratione materiae, includes the discipline of the central bank law, the commercial bank law (banking law) and the monetary law, which refers to governing 
the issue of defining a monetary unit and determining the legal tenders for issuing money (Aufucht, Evensen, 1976, pp. 1-10). ${ }^{1}$

The theses on the existence of the so-called free banking in which healthy competition between commercial banks would result in the desired monetary qualitative leap, is not sustainable considering that the central bank, as a non-profit institution, establishes control in the banking and monetary systems as a whole. We are of the opinion that the formation and operation of the European Economic and Monetary Union (EMU) was, and has been, crucial for the further divergence of central bank law, notwithstanding the institutional crisis and the obvious asymmetry between the weak general economic policy and centralized monetary policy. The EU monetary law is highly developed and it is the benchmark of the national monetary legislation of Member States, as well as countries on the path to European integration (and the Union's foreign trade partners, too) who must be aware of it because of the monetary elements of foreign trade cooperation. Given the fact that the central bank is the basic subject of monetary law, it is clear that the central bank enjoys a special legal status in the national legal order. However, for the reasons of legal certainty, its creativity in the creation, implementation, derogation and abrogation of monetary legal norms (as well as the general financial norms that it creates with the acquisition of new competencies in the field of financial stability) must be placed under adequate scrutiny, implying that there are such controversial and insufficiently explored question in literature dealing with the issue of legal liability for the damage it may cause in its work.

\section{PILLARS OF CENTRAL BANK GOVERNANCE AS PREREQUISITE FOR DEFINING LEGAL RESPONSIBILITY}

In the monetary law literature, the central bank governance is viewed as a heterogeneous concept of the principles of independence, accountability and transparency, which is in the function of creating an optimal basis for the work of the central bank pertaining to legal regulation (Goodhart, 1991, p.6). In defining the concept of responsibility in the work of the central bank, it is important to note that the above mentioned principles stand in close synthetic-dialectical connection and should not be viewed in an isolated plane since the positive and negative correlations of their connectedness can be the cause of irregularities in the work and therefore causing damage. The positive and negative correlations can be expressed in a different degree depending the type of acts that a bank

\footnotetext{
${ }^{1}$ However, in some monetary jurisdictions, there has been an integration of the first and third substantive discipline, and so the central banks' law regulates the basic monetary issues.
} 
makes and a different understanding and interpretation in practice which can be a consequence of making decisions on regular or extraordinary occasions. We believe that in this context it is particularly important to emphasize that the ban on soft budgeting, i.e. the monetization of the public debt (which is established by almost all monetary legislation in the world) can have significant consequences to the question of the central bank responsibility. However, when this damage is caused by gross negligence of employees, the potential damage in monetizing debt is reflected in the fact that diverting the central bank policy from its main task (monetary stability) and insisting on government debt lending has its opportunity cost (harm), because the central bank could effectively use that time to work in order to ensure the monetary stability that has the character of pure public good.

The optimal management of the central bank must be based on the following principles: defining price stability as the primary objective of the monetary policy to reduce direct lending to government debt; ensuring full functional independence for establishing foreign exchange policy; noninterference of executive authorities (direct or indirect) in the selection of foreign exchange policy measures and instruments; the creation of normative conditions in which responsibility in work corresponds to the degree of the independence of the bank and; providing by-laws that enable transparency to match the degree of the achieved accountability while deepening the financial market (Scheller, 2006, pp. 238-244). The competence of the central bank is not definitively defined and it must be viewed in real terms, beyond the current legal solutions, and shaped in the manner that always leaves sufficient room for maneuvering in order to acquire certain new competencies necessary for monetary crisis stabilization. Within its regulatory powers, the central bank can adopt different types of legal acts. According to their effect and territorial scope, we can classify them into acts that have the general legal effect and acts with internal effect. The law created and enforced by the central bank is softer than the hard law in its nature. However, in the context of the global economic and financial crises, its legislative competence has been given a coherent dimension (most notably in the ECB's example), as confirmed by the ECJ in the outright monetary transaction (OMT) case judgment. Given the fact that monetary laws, to a certain extent, can also respect economic logic, the central bank indeed seeks to create optimal legal conditions by exercising its statutory powers to achieve a high degree of independence, accountability, transparency and democratic legitimacy. Due to the effects of the Euro crisis, many central banks have begun to play the role of the last bank resort. By this concept the central bank grants loans to all institutions with liquidity problems (i.e. the ability to settle their due financial obligations), but under certain conditions: the financial support is (usually) intended for banks to regulate their solvency; the financial support is not time-limited or sum-limited, and the support lasts for as long as it is justified. However, 
certain penalties in terms of default interest may be collected in certain cases, and these include the central bank requests to deposit certain types of pledges from commercial banks and discretionary assessment of credit (non) approval in case-specific assessments (Steinbach, 2016, p. 364).

The effective implementation of monetary law is not possible without the central bank's independent position and the non-intervention of the executive in its field of work (Gleson, 2019, p.72). However, this should not be understood in the light of the existence of an absolute ban on the central bank's communication with other institutions and cooperation with other national banks since it is not prohibited and harmful in all circumstances, but rather, desirable and useful in balancing the values, tasks and functions of the monetary policies of its members. It can be noted that although these are primary law norms that have an imperative character (ius cogens), states (governments) often behave as if they were the dispositive norms that best reflect the consequences of the global financial crisis that imposed different ECB reactions for the survival of the monetary union. Moreover, the establishment of cooperation between central banks in international monetary law is necessary for the realization of international stability. Such co-operation may, in practice, take the form of: information exchange (which is established by special agreements between central banks, laying down the conditions for such exchange of standardized concepts with the purpose of filling in the gaps in the information exchange process); dialogues and exchanges of views on monetary goals; exchanges of impressions and beliefs about economic development, and; standardized techniques for the exchange of data in their area of competence (which is important for mutual comparisons and joint actions). Of course, it is best for central banks to cumulate these forms of cooperation in practice because that way they become aware of the need to develop new forms of cooperation that will enable their tasks to be fulfilled in an optimal way. Although, we fundamentally agree with the view that the central bank must also have the aforementioned powers, it is essential that a restrictive approach is applied in the implementation of these new powers and that this function remains only secondary. The potential negative consequences of extensively practiced rescuing powers would be reflected in moral hazard, i.e. such behavior by the governments that would knowingly risk deviating from the criteria set out in the monetary strategy and failing to respect fiscal rules as constitutional and legal constraints on public debt by counting in advance on the bail-out. ${ }^{2}$

The relations between the government and the central bank have historically been the subject of much controversy, primarily in the segment

\footnotetext{
${ }^{2}$ The consequences of such moral hazard could overflow and threaten to undermine
} the global monetary order protected by international monetary law. 
of state-owned banking, separate legal personality and work independence (Conti-Brown, Lastra, 2018, p.187). However, in all constitutional texts, only the institutional (not functional independence) of the central bank is affirmed, but in the future functional independence must also be explicitly established by an act of the highest legal force (Goodhart, 2005, pp. 206215). The main argument refers to the need of reducing the influence of the political factors in meeting the public needs of citizens, but at the same time, the central bank's contribution to the previously established goals in the field of public services. A further argument relates to the fact that all laws in one country are created by the legislative and executive branches, but a potential problem may arise when the executive branch takes dominance over the legislative, so a legal imperative is posed by a broadbased judicial authority that strikes a balance between these forms of government. Functional independence is also necessary because the central bank evolves in the context of globalized economic flows (and thus contributes to maintaining financial stability), so the central bank can be seen as a separate fiscal agent. Although the number of goals for which central banks have competencies is complicated, we cannot say that there are competitive relations between them and there is no place for any tradeoff, because, in our view, there is, a complementarity ratio, not an exclusivity ratio between them.

The dominant position of the central bank in national monetary law was particularly confirmed during the 1970's and 1980's, when the dominant monetary theory advocated a greater degree of national monetary policy orientation in pursuing international price stability. Such monetary doctrine was based on three basic postulates: the existence of a natural rate of unemployment; adjusting the nominal exchange rate to the national purchasing parity with a stable relationship between the desired growth in monetary demand and national income (Goodhart, 1995, p. 213). The central bank appears largely as a politically independent institution whose work is subject to the concept of democratic accountability. Liability is interpreted in a broad sense and refers not only to the issue of the central bank's mandate, but also to the specific actions it assumes to achieve the objectives of the single monetary policy. In the monetary law literature, it is emphasized that the responsibility has three dimensions: deciding to define the goals of the common monetary policy and their hierarchy, announcing the actual monetary policy, and determining the final responsibility for monetary policy actions (Haan, 2010, pp. 119-120). Taking into account the concept of democratic legitimacy according to which the power of all state-political institutions originates and returns to the citizens, a distinction can be made between the so-called input (procedural) legitimacy and output legitimacy (Scheller, 2006, p.127). The procedural legitimacy exists when entities make decisions based on the powers delegated by citizens, while the legitimacy of the results is assessed in relation to the fact that the 
elected mandates have fulfilled their expectations and needs. According to this theoretical assumption, the central bank enjoys the procedural legitimacy, which results from the delegation of monetary sovereignty from the state to the supranational level of government. It is noticeable that the independence and responsibility of the central bank cannot be analyzed per $s e$ because they represent the conditions that must be cumulatively fulfilled. Based on the above, we can see that it is necessary to establish a certain balance in the requirements for independence and accountability, since the central bank must prevent events in which subjects and actions of monetary policy might become the object of interests to the entities and the operation of fiscal policy instruments (Hazel, 1997, p. 59).

In contemporary monetary law, the relationship between the central bank and the government cannot be reduced to a simple rethinking of its independence, since in practice it is much more (Lastra, 2015, p. 401). Throughout history, central banks have built a specific (we would say) twoway freight business in their dealings with the government in which the government is expected to fully fulfill its pre-emptive requirements, while the central bank is expected to fulfill certain prestations by allowing the government a privileged position, which in fact means lending to its debts. When it comes to the relationship between independence, accountability and transparency in the work of central banks, empirical research shows that there is a high degree of correlation between the degree of transparency and accountability (Laurens, 2009, p.171). Namely, if the central bank shows a high degree of responsibility in its work, it implies a high level of transparency as well. Accountability is primarily seen as the presence of clearly defined goals that a bank wants to achieve, while transparency stands for the public disclosure and publication of macroeconomic considerations that determine a particular type of monetary policy. It is quite logical that clearly defined goals allow the central bank to communicate detailed information on monetary strategy, medium-term outcomes, as well as the adopted mathematical models and assumptions. Although, at first glance, it may seem that the developed and complex economic system includes a high degree of accountability at work (which would be a feature of developed economies), and the low level of transparency and low degree of accountability at work would revolve as features of underdeveloped countries, it may not always be so. ${ }^{3}$

We believe that transparency must also raise the question of its real reach (scope), because monetary laws are not lex certa (they are not written in a style that all citizens can understand, and thus make it even

\footnotetext{
${ }^{3}$ Such discrepancy, according to some IMF studies, is due to the fact that the degree of transparency can be relatively easily increased by issuing more publications on the central bank work, while increasing accountability in the work requires a change in the central bank legislation, which is a more complex process.
} 
harder to understand the by-laws and secondary law acts that the central bank adopts). The requirement for clarity and precision in monetary laws must suffer (justifiable) limitations, and therefore monetary regulation is not codified in any monetary jurisdiction. Such codification would be so difficult to achieve (from a legal and technical standpoint) and would be very complex for implementation due to its extraterritorial monetary effects. In order to understand monetary regulation, it is necessary to adopt specialized legal knowledge that only a limited number of lawyers possess, so transparency (in an effective sense) can only be achieved by the dissemination of monetary law discipline through the scientific and professional public, and not by the general public (or at least not in terms of the same quality as previously mentioned).

\section{MONETARY LAW ARRANGEMENTS FOR CENTRAL BANK LEGAL RESPONSIBILITY AND PROTECTION: AN OVERVIEW}

When we talk about the legal responsibility of the central bank, we must point out certain similarities in the work of central banks and supreme courts. Specifically, there are certain evolutionary links in the development of the judiciary and central banking that are best reflected in the fact that the government entrusts the authority to exercise the most important monetary and judicial powers to these institutions whose members it appoints, but they must act in favor of the internal affairs of the entire society, although they are not their direct elect (Goodhart, Meade, 2004, p. 5). Although their constitutional position is similar, there are no a priori reasons to expect that supreme court decisions will have many elements in common with monetary policy decisions, but we must bear in mind that monetary policy is not governed per se, but by adequate legal regulations.

In the monetary law literature, with respect to central bank accountability, a distinction is made between a regime of fault liability and no fault liability, where, despite the absence of a subjective element, there is liability for the consequences (Dijkstra, 2012, p. 344). The responsibility of the central bank can be caused by negligence or gross negligence (intentionally) when the act of the bank is not in accordance with "good faith", which is definitely expected on the part of such an institution. Also, in terms of the type of liability, the distinction is made between the responsibility for conducting monetary policy, responsibility for financial supervision and responsibility for resolution measures. The tripartite polarization of responsibilities is conditioned by the evolution of the central bank roles, which in the context of the global financial crisis, begin to perform some new functions. The issue of legal liability is further complicated by the fact that central banks are also receiving some new tasks in the field of money laundering counter-actions, counter-terrorism 
financing, and issues of regulating digital currencies. Also, the central bank has a significant role in the legal framing of the banking risk management (Jovanović, Zattila, 2018, p.142). When it comes to the central bank legal responsibility, most national legal texts that regulate their establishment, jurisdiction and action today (in over 150 monetary jurisdictions monitored by the IMF) do not explicitly identify the object of protection against harmful activities of the central bank. The tort liability clause of the central bank is (generally) included in the monetary norms of the law, except in the case of the liability of the Chilean central bank where such liability is not regulated by law, but is prescribed by the constitution as an objective liability of the state decentralized agencies (Khan, 2018, pp. 15-26). The liability imposed by monetary laws is almost always narrowly limited in all monetary jurisdictions, and very often linked to the immunity from liability for particular categories of employees of the central bank. Most often, they are members of the board of governors who, for example, were abstinent in making potentially harmful decisions or implementing measures with such an effect on the economy and citizens. The necessity of supplementing and concretizing such provisions lies in the need to clearly define the nature and scope of liability, given that in some monetary jurisdictions tort liability is only determined by the central bank (but very often combined legal liability decisions are met). Although liability rules all civil servants, certain modifications exist in terms of the reasons for granting immunity from prosecution, which is quite expected given the fact that the central bank is an actor primus in establishing monetary order and the application of all monetary prerogatives found in the structure of monetary sovereignty, especially lex cudenate monetae (Dimitrijević, 2018, p. 41). The specific institutional status obliges all central bank employees to act in de lege artis, but that does not mean that there have been no cases of tort liability in monetary history. Prior to the outbreak of the debt crisis (2008), the IMF's Department of Monetary and Capital Markets (IMF) collected significant data and reports that called for accountability of central bank employees on the territory of Europe and the Asia-Pacific region related to the exercise of the function of financial supervision, the implementation of certain directives and acts related to the prevention of money laundering. Most legal texts state that a member of the supervisory board would not be held liable for any damage incurred in the performance of their regular duties, except where such damage was intended to be incurred (with the employees' right being receive compensation in the case of discharge).

However, we must point out here that the legal provisions never distinguish between civil, administrative and criminal liability of central bank employees, nor establish specific sanctions for such liability. Exceptions are the central bank laws of the Philippines, Dominican Republic, Lithuania and Ecuador, which make a clear distinction between the types of mentioned liability. It should be noted that these are the monetary 
jurisdictions whose impact in creating the international monetary order is (in practice) far weaker than the impact of monetary jurisdictions of highly developed countries, which indicates a high level of awareness of national monetary legislators, and an enviable level of monetary nomotechnics development that does not leave legal gaps in one such significant component of the supreme monetary institution responsibility. Similar ambiguities exist with regard to the categories of employees who enjoy immunity, since they are most often determined en-general, with some exceptions (the immunity of auditors, structural units or regional management). It is our opinion that this is actually a legal standard the content of which must be determined by the court in each case depending on the situational framework and social circumstances (which can potentially prolong the protection of the legal order). It is necessary to transform such standards over time into concrete monetary norms, i.e. legal articles where the enumeration method could indicate the categories of employees who enjoy protection and under what conditions it can be applied (justified) in practice. Such concretizations, in our view, would greatly contribute to the demystification of the employment status of central bank employees in the eyes of the general public and would show the readiness and unwavering determination of monetary legislators to contribute to the full realization of the principle of legal equality. Taking into account some bad examples from monetary history, namely the work of certain central banks and their gross misuse of powers, such enumeration finds its logical and ethical justification. This, of course, does not mean that direct liability for damages would apply only to the lower categories of employees, since higher liability implies deeper knowledge and compliance with legal norms (which is a condition for promotion in the service), greater caution and thoughtfulness in decision making event which have a macroeconomic effect. Excluding the responsibilities of senior central bank officials, hypothetically, could also lead to the emergence of a moral hazard phenomenon, a relationship of conscious deliberation that would be absolutely unacceptable in the context of monetary stability.

A major drawback of the central bank laws is the apparent lack of standards and accountability criteria, since in very few cases can we find defined liability caused by negligence, gross negligence or good faith. For example, central banking laws of New Zealand, Mauritius and Seychelles contain detailed descriptions of liability for damage caused by acting in good or bad faith, while laws on central banks of Serbia, Croatia, Belgium and Honduras prescribe negligence as a measure of liability (Ibid). Also, the solatium is explicitly established in a small number of monetary laws, which means that it remains subject to interpretation, which in practice can be problematic when applying the principle of substantive truth. It is interesting that in the monetary legislation of New Zealand, the obligation of compensation actually belongs to the government which decides on the proposal of the competent minister. The clear definition of the type of 
sanction in the legal text leaves additional problems in the case law, however the exception is the law on the Luxembourg central bank which ultimately contains provisions for sanctions for employees in the event of breach of their responsibilities which are complementary to the Luxembourg Criminal Code. Up to now, the amount of fines imposed for the breach of the aforementioned provisions on central banks work has most often been set in the range of $\$ 7-700,000$, while the duration of the sentences imposed has been set in the range of three months to twenty years (Ibid). Interestingly, in all monetary jurisdictions, a combination of personal and material executions is encountered, while only the Seychelles and Ghanaian central bank law determine that the court must make a choice in this case, indicating that it is a specific mechanism of accountability (Khan, 2017, p. 3).

\section{AN EMPIRICAL EXAMPLE OF THE SERBIAN MONETARY LAW IN THE CONTEXT OF THE LEGAL PROTECTION OF THE CENTRAL BANK}

When it comes to legal protection of the National Bank of Serbia, it should be noted that it has traditionally been limited to liability for damage that bank employees may cause through their work. Interestingly, the amendments to the National Bank's law, introduced 2010, in art. 86b, include a provision that forecloses the objective liability of the bank, its organs and employees and imposes the principle of subjective liability, which effectively prevents injured persons from receiving compensation for damage caused by the illegal acts of the central bank. On that occasion, the complainant pointed out that the constitutional rights of the potentially injured persons were seriously violated, which (if the said provision had remained in force) would have been obliged to prove the intention or extreme negligence for the damage which is contrary to the principle established in Article 35 of the Constitution of the Republic of Serbia. Interestingly, the earlier (2003) Law on the National Bank did not contain a provision that would regulate the liability of the National Bank for the damage arising from the performance of its operations, as amended by the new Law (2010), where for the first time it is deciduously established. We believe the legislator has shown a willingness to put the supreme monetary institution on the same responsibility pattern with other state agencies in the manner prescribed by the Obligations Law, which was a significant monetary-legal qualitative shift.

However, the way in which this liability was formulated shows a departure from the sense of the indemnity institution, since the mentioned Art. 86b provided that "the National Bank of Serbia, the Governor, the Vice Governors and other employees shall not be held liable for damage arising in the course of their business unless it is proved that such damage was caused by intentional or gross negligence (par. 1); the employees referred 
to in this paragraph cannot be held liable even after termination of their employment with the National Bank of Serbia, or termination of their function (par. 2), and that the National Bank of Serbia shall reimburse the costs of representation in court and administrative proceedings against employees." In considering the fact issues in this case, the Constitutional Court started from the fact that the National Bank represents a special republican body (sui generis body), that it has the status of a legal entity and so it can be the holder of rights and obligations in legal transactions. Its bodies do not have an independent and separate legal existence, and therefore no delinquent capacity, because they represent the constituent parts of the bank as a legal entity. From this fact, in the Court's view, it follows that the National Bank is liable for the damage caused by its organs by unlawful or irregular work. It is also unambiguous from the court's decision that the National Bank's tort liability is based on the misconduct of its authorities, which may be manifested in the form of illegal or irregular work. In this regard, the Constitutional Court points out that in legal theory and jurisprudence the view prevails that unlawful work of an authority implies any act of an organ contrary to the law, i.e. regulations made on the basis of the law (including the failure to apply the law), and as malfunctioning of an authority means any misconduct by an authority that is contrary to the certain standards of treatment of a legal entity in a given circumstance according to a certain pattern of treatment (the so-called "caring" entity), including actions contrary to the rules of profession. It is basically a legal standard of expected behavior (which is higher if it is a legal entity that has concrete legal powers). On the other hand, a single person who (as an organ or an employee), causes damage in the performance of the National Bank's operations cannot be held liable for civil liability, but may be subject to recourse.

In this manner, the Court emphasizes that everyone has the right to compensation for pecuniary or non-pecuniary damage caused by unlawful or irregular work by a governmental authority, a public authority holder, an autonomous province authority or a local government body where the National Bank cannot be an exception. Therefore, on the basis of the linguistic and purposeful interpretation of this constitutional provision, in the Court's view, it follows that the Constitution does not bind the aforementioned guarantee of the right to compensation in the aforementioned cases for the fulfillment of any other condition relating to the determination of the guilt degree which caused damage to third-party persons. On the other hand, the Constitutional court points out that the issue of direct liability of the members of individual bodies (employees of the National Bank towards third parties who have been harmed) should be viewed separately from the issue of liability of the National Bank as a legal entity. At the same time, the Court based its assessment on the fact that the impugned legal decision deviates from the principle that a legal person is 
liable for damage caused by its organ to a third party in the exercise of its functions established by Art. 172 of the Obligations Law. It is the view of the Constitutional Court that the impugned standardization violates the principle of unity of the legal order, expressed in Article 4(1) of the Constitution, which requires mutual harmonization of all regulations and legal acts in order to protect both individual rights and interests, and the general public interest.

It is important to note that the Constitutional Court's decision was announced with some delay from the moment of its adoption, and that in the meantime a new Law on Central Bank (2015) was adopted in Parliament, in which the provision of Art. 86 (b) was audited in such a way that the National Bank is only liable for damage resulting from non-performance in good faith. Certainly, the aforementioned decision of the Constitutional Court and the amendments to the National Bank Law substantially contributed to the establishment of final positions on whether the central bank responsibility should be defined in an absolute, unlimited or objective manner with respect to domestic interests and comparative practice. Certainly, such a legal solution in the domestic monetary law is not lonely, since many comparative texts contain similar solutions, and we believe that it is in the function of strengthening the components of democratic legitimacy and the transparency of its work. The potential dissatisfaction with the current provisions on the responsibility of the National Bank should not reflect the understanding of the work of the central bank as a classical public administration body (because it certainly is not), and such a statement would imply a rude simplification and the negation of its importance in creating, developing and disseminating the spirit of monetary law over many centuries, the credible protection of monetary sovereignty and its contribution to the creation and maintenance of the international monetary system. The aforementioned legal solutions are not given ad infinitum and pro futuro, but with sufficient room for maneuvering to redefine them, given the constant evolution of the central bank's role in contemporary economy and law, which is particularly observed in the context of the globalization of economic and capital flows, as well as in the remediation of debt crisis consequences.

Nevertheless, the responsibility of the central bank is coextensive with its independent status (Golubović, 2018, p. 80). At the same time, we need to be aware that monetary policy is not just an ordinary set of administrative activities that must be brought under judicial control in order to exercise and protect individual rights, but implies the use of complex techniques and models aimed at sustainable economic growth which judges usually do not understand. While it is clearly understood by jurists that laws must be effective, the fact is that the concept of efficiency still remains a little abstract today, as it is primarily determined by the mechanics of designing legal solutions which include a careful 
selection of doctrinal and legal concepts, form, language, style, and luck in regaining the right of certain views (Mousmoti, 2019, p. 7). In the field of monetary law, as a hybrid branch of law with represented private and public interests, the requirement of normative efficiency is further complicated because of monetary legal norms' dialectical connection with economic law and the condition of economic efficiency.

\section{CONCLUSION}

The central bank is the main subject of the national monetary law, and as such the principal interpreter and addressee of all the components arising from monetary sovereignty delegated to it by the state. Its institutional sui generis position signifies that the central bank also emerges as the creator of its own law, which undoubtedly confirms the process of the disintegration of monetary law, in which the law of central banks is the first and oldest special legal discipline that has developed from it. Such a position of the central bank certainly does not mean that its work takes place outside the positive legal order, which also involves regulating the issue of legal (tort) liability for the cause of damage when performing activities within its scope. The legal regulation of such liability is a direct manifestation of its passive procedural legitimation and the increasing frequency of monetary disputes in which it participates. Although there are no uniform legal solutions regarding the nature and type of tort liability of the central bank and the mechanism of redress, we must emphasize that in all monetary jurisdictions there are legal solutions recognizing and concretizing such liability to a greater or lesser extent. Our opinion is that according to the new role of the central bank in the area of financial supervision and macroprudential policy, it is necessary to set transparent rules that will not violate the right to equal compensation for the caused damage and the consistent application of constitutional provisions. However, at the same time, it is important to explain that the central bank is an institution sui generis and that its officers act de lege artis, which does not mean that they are infallible.

\section{REFERENCES}

Amtenbrick, A. (2005). The Three Pillars of Central Bank Governance - Towards a Model Central Bank Law or a Code of Good Governance?. Current Developments in Monetary and Financial Law, Vol. 4, 101-132.

Arner, D.W., Panton, M., Lejot, P. (2010). Central Banks and Central Bank Cooperation in the Global Financial System. Global Bussines and Development Law Journal, 1(42), 200-211.

Aufucht, H., Evensen, J. B. (1976). Central Banking Legislation: A Collection of Central Bank, Monetary and Banking Law, Vol. II. Washington: IMF Press.

Conti-Brown, P., Lastra, M. R. (2018). Research Handbook on Central Banking. London: Edward Elgar Publishing. 
Dijkstra, R. J. (2012). Liability of Financial Supervisory Authorities in the European Union. Journal of European Tort Law, 3, 344-377.

Effiros, R. C. (1994). Currnet Legal Issues Afecting Central Banks. Washington: IMF Press.

Gleson, S. (2018). The Legal Concept of Money. Oxford: Oxford University Press.

Golubović, S. (2018). Pravni osnov odgovornosti Narodne banke Srbije za očuvanje monetarne i

finansijske stabilnosti (The legal basis of the National bank of Serbia's responsibility for preserving monetary and financial stability). Zbornik radova Pravnog fakulteta $u$ Nišu 81, 69-82.

Goodhart, C. (1991). The Evolution of Central Banks. Cambridge Massachusetts: The Mitt Press.

Goodhart, C. (1995). The Central Bank and the Financial System.Cambridge Massachusetts: The Mitt Press.

Goodhart, C. (2002). The Constitutional Position of an Indipendent Central Bank. Government and Opposition, 37, 190-210.

Goodhart, C., Meade, E. (2015). Central Banks and Supreme Courts. Financial Markets Group Special Papers 153.

Dimitrijević, M. (2018). Institucije međunarodnog monetarnog prava (International Monetary Law Institutions). Niš: Centar za publikacije Pravnog fakulteta.

IУз-1243/2010 od 23.12.2014.

Khan, A. (2017). Central Bank Legal Frameworks in the Aftermath of the Global Financial Crisis. IMF Working Paper 17/101.

Khan, A. (2018). Legal Protection: Liability and Immunity Arrangements of Central Banks and Financial Supervisors. IMF Working Paper 18/176.

Lastra, M. R. (2015). International Financial and European Monetary Law. Oxford: Oxford University Press.

Laurens, B. et Al. (2009). Central Bank Indipendance, Accountability and Transparentcy. London: Palgrave Macmilan.

Mousmoti, M. (2019). Designing Effective Legislation. London: Edward Elgar.

Scheller, H. K. (2006). The European Central Bank: History Role and Functions. Frankfurt am Mein: ECB Press.

Smits, R. (1997). The European Central Bank: Institutional Aspects. The Hague, London \& Boston:Kluwer Law International.

Steinbach, A. (2016). The Lender of Last Resort in the Eurozone. Common Market Law Review 53, 361-383.

Zattila Jovanović, M. (2018). Upravljanje bankarskim rizikom (Risk Management in Banking). Zbornik radova Pravnog fakulteta u Nišu 81, 139-149.

Zakon o Narodnoj banci Srbije (Law on Serbian Central Bank) Službeni glasnik RS. бp. 40 (2015). 


\title{
О ПРАВНОЈ ОДГОВОРНОСТИ ЦЕНТРАЛНЕ БАНКЕ У МОНЕТАРНОМ ПРАВУ
}

\author{
Марко Димитријевић, Срђан Голубовић \\ Универзитет у Нишу, Правни факултет, Ниш, Србија
}

\section{Резиме}

Централна банка јесте основни субјект монетарног права и, сходно томе, ужива посебан правни статус у националном правном поретку. Из разлога праве сигурности, њена креативност у стварању, примени, дерогацији и аброгацији монетарних норми мора бити постављена под адекватну контролу, што имплицира и контроверзно и у литератури недовољно обрађено питање одговорности за штету коју у свом раду може проузроковати. Менаџмент централне банке посматра се као хетерегони концепт принципа независности, јавности у раду и одговорности који се налази у функцији стварања оптималне основе за правно регулисање рада централне банке. У утврђивању концепта одговорности у раду централне банке, важно је напоменити да поменути принципи стоје у тесној синтетичко-дијалектичкој повезаности и да се не смеју посматрати у изолованој равни, јер заправо позитивне и негативе корелације различитог степена њихове повезености (која је изражена у другачијем степену зависно од врсте аката које банка доноси и другачијим поимањем у пракси, што јесте последица доношења одлука у редовним или ванредним приликама) могу бити узрок неправилности у раду и, самим тим, проузроковања потенцијалне штете.

У теорији монетарног права се у погледу одговорности централне банке прави дистинкција између режима скривљене одговорности и одговорности без кривице, где без обзира на одсуство субјективног елемента постоји одговорност због насталих последица. Одговорност централне банке може бити проузрокована нехатом или грубом непажњом (намерно), тј. непоступањем са „добром вером”. Такође, у погледу врсте одговорности, праве се разлике између одговорности за вођење монетарне политике, финансијске супервизије и резолутних мера. Трипартитна поларизација одговорности условљена је еволуцијом улоге централне банке, која у условима током и након глобалне финансијске кризе почиње обављати и функцију финансијске супервизије. Проблематику правне одговорности додатно компликује чињеница да централне банке добијају и неке нове функције у области спречавања прања новца, сузбијања финансирања тероризма, као и питања регулисања дигиталних валута. Одредба о деликтној одговорности централне банке је, по правилу, укључена у монетарне норме закона и готово је у свим монетарним јурисдикцијама уско ограничена и повезана и са имунитетом од одговорности за поједине категорије запослених у централној банци. Иако се на одговорност запослених у централној банци примењују правила о одговорности која важе за све државне службенике, одређене модификације постоје у смислу разлога за давање имунитета од гоњења, што је сасвим очекивајуће узевши у обзир чињеницу да је централна банка actor primus у установљавању монетарног поретка и примени свих монетарних прерогатива који се налазе у структури монетарног суверенитета, посебно lex cudenate monetae. 